\title{
Efek minuman cokelat (Theobroma cacao L.) terhadap peningkatan jumlah eritrosit dan kadar hemoglobin tikus putih anemia
}

\author{
Arisanty Nur Setia Restuti*, Adhiningsih Yulianti, Dewi Lindawati
}

\begin{abstract}
Background : Anemia is a condition when the body do not have enough healthy red blood cells. Laboratory sign of anemia is decreases of erythrocytes and haemoglobin $(\mathrm{Hb})$ level. Anemia can be caused by deficiency of nutritional intake.

Objectives: The purpose of this study was to determine changes in the number of erythrocytes and Hb levels of anemia rats which were intervened with chocolate drinks.

Methods : The design of this study was an experiment with a pretest-posttest control group design. The samples in this research were 21 male wistar rats. Rats were induced by $\mathrm{NaNO}_{2} 25 \mathrm{mg} / \mathrm{gBB}$ for 18 days, then followed by an intervention of chocolate drink $4.3 \mathrm{ml} /$ day for 14 days. The results will be tested using one way ANOVA test and paired T-Test.

Results : The results of this study showed that there were significant differences in the number of erythrocytes and Hb levels between groups before the intervention $(p=0.00)$ and $(p=0.011)$, so also after the intervention there is significant differences in the number of erythrocytes and Hb levels between groups $(p=0.00)$ and $(p=0.01)$.Paired T-Test results showed that there were significant differences in the number of erythrocytes and Hb levels before and after the study in the intervention group given chocolate drink $(p=0.00)$ and $(p=0.02)$.
\end{abstract}

Conclusion : Chocolate drinks have an effect on increasing the number of erythrocytes and Hb levels in anemia rats.

Keywords: anemia; chocolate; erythrocytes number; hemoglobin

\begin{abstract}
ABSTRAK
Latar Belakang : Anemia lebih dikenal sebagai penyakit kurang darah yang ditandai dengan berkurangnya jumlah eritrosit dan kadar hemoglobin $(\mathrm{Hb})$ hingga dibawah normal. Anemia dapat disebabkan oleh defisiensi asupan gizi dari makanan.

Tujuan : Penelitian ini ingin mengetahui perubahan jumlah eritrosit dan kadar Hb tikus anemia yang diintervensi minuman cokelat.

Metode : Desain penelitian ini adalah eksperimen dengan pretest-posttest control group design. Jumlah sampel yang digunakan yaitu 21 ekor tikus putih jantan galur wistar yang terdiri dari 3 kelompok. Kelompok kontrol negatif adalah kelompok tikus normal, sedangkan kelompok kontrol positif adalah kelompok tikus anemia, sedangkan kelompok perlakuan adalah kelompok tikus anemia yang diintervensi minuman cokelat 4,3ml/hari selama 14 hari. Induksi menggunakan $\mathrm{NaNO}_{2}$ $25 \mathrm{mg} / \mathrm{gBB}$ selama 18 hari supaya tikus menjadi anemia. Hasil penelitian akan di uji beda antar kelompok menggunakan uji one way ANOVA sedangakan uji beda sebelum dan setelah perlakuan dalam kelompok menggunakan uji paired T-Test.

Hasil : Hasil penelitian ini menunjukkan terdapat perbedaan signifikan jumlah eritrosit dan kadar Hb antar kelompok perlakuan sebelum intervensi $(p=0,00)$ dan $(p=0,011)$ hal ini menunjukkan bahwa pada tikus yang diinduksi sudah mengalami anemia, begitu juga setelah intervensi ditemukan perbedaan yang signifikan jumlah eritrosit dan kadar Hb antar kelompok perlakuan $(p=0,00)$ dan $(p=0,01)$.

Hasil uji paired T- Test menunjukkan terdapat perbedaan signifikan jumlah eritrosit dan kadar Hb sebelum dan setelah penelitian pada kelompok perlakuan yang diberi intervensi minuman cokelat $(p=0,00)$ dan $(p=0,02)$.

Kesimpulan : Minuman cokelat berefek terhadap peningkatan jumlah eritrosit dan kadar Hb tikus anemia.
\end{abstract}

Kata kunci : anemia; coklat; jumlah eritrosit; hemoglobin

\section{PENDAHULUAN}

Anemia atau penyakit kurang darah ditandai dengan berkurangnya eritrosit hingga dibawah normal ${ }^{1}$. Hemoglobin $(\mathrm{Hb})$ merupakan komponen eritrosit dan protein konjugasi yang berfungsi untuk membawa oksigen ke seluruh jaringan tubuh ${ }^{2}$. Anemia menyebabkan transportasi oksigen terganggu sehingga jaringan tubuh orang yang mengalami anemia akan mengalami kekurangan oksigen ${ }^{1}$.
Penderita anemia zat besi diperkirakan mencapai $30 \%$, dimana prevalensi tertinggi berada di negara berkembang seperti di Indonesia, India dan Malaysia. Prevalensi anemia adalah sekitar 8-44\%, dengan prevalensi tertinggi pada laki-laki usia 85 tahun atau ${ }^{l e b i h}{ }^{3}$. Hasil studi lainya dilaporkan bahwa prevalensi anemia pada laki-laki adalah $27-40 \%$ dan wanita adalah $16-21 \%{ }^{4}$. Prevalensi anemia di Indonesia sendiri yaitu $21,7 \%$ dengan penderita anemia berumur 5-14 tahun sebesar $26,4 \%$ dan $18,4 \%$ penderita berumur $15-24$ 
tahun $^{5}$. Data Survei Kesehatan Rumah Tangga (SKRT) tahun 2012 menyatakan bahwa prevalensi anemia pada balita sebesar 40,5\%, ibu hamil sebesar $50,5 \%$, ibu nifas sebesar $45,1 \%$, remaja putri usia 10-18 tahun sebesar $57,1 \%$ dan usia $19-45$ tahun sebesar $39,5 \%$.

Hemoglobin yang rendah menunjukkan terjadinya anemia. Anemia ditandai dengan gejala berupa tubuh cepat lelah, jantung berdebar, mual dan muntah, mata berkunang-kunang, rambut rontok, perubahan bentuk kuku, penurunan sistem imun, sering pingsan, sesak nafas, kulit terlihat pucat, kelopak mata tampak pucat, sakit kepala atau pusing. Kadar $\mathrm{Hb}$ dapat dipengaruhi oleh tersedianya oksigen pada tempat tinggal, misalnya $\mathrm{Hb}$ meningkat pada orang yang tinggal di tempat yang tinggi dari permukaan laut. $\mathrm{Hb}$ juga dipengaruhi oleh posisi pasien (berdiri, berbaring), dan variasi diurnal (tertinggi pagi hari) ${ }^{7}$. Anemia kronis dapat menyebabkan anoksia pada jaringan dan organ, sehingga dapat menghambat kerja organ dan produksi energi dari $\mathrm{sel}^{8}$. Flavonoid merupakan senyawa aktif polifenol yang berperan sebagai antioksidan, yang dapat meningkatkan eritropoiesis (proses pembentukan eritrosit) dalam sumsum tulang dan memiliki efek immunostimulan. Sifat antioksidan ini dapat menjaga haeme iron tetap dalam bentuk ferro yang berhubungan dengan produksi methemoglobin. Dengan adanya flavonoid saat terdapat bentuk ferryl $\mathrm{Hb}$ diperkirakan dapat mencegah setengah dari molekul oxyHb teroksidasi menjadi metHb. Sehingga hemoglobin tetap dapat menjalankan fungsinya untuk mengikat oksigen karena tetap terdapat dalam bentuk oxyHb ${ }^{4}$.

Cokelat (Theobroma cacao L.) berpotensi besar sebagai pemasok bahan antioksidan dengan kandungan total flavonoid $316,9 \mathrm{mg} / \mathrm{l}$ yang tersusun dari beberapa molekul fenol ${ }^{9,10,11}$. Flavonoid merupakan senyawa polifenol yang berperan sebagai antioksidan, yang di dalam sel darah dapat bertindak sebagai penampung radikal hidroksil dan superoksida sehingga melindungi lipid membran dan mencegah kerusakan sel darah merah $^{12}$. Penelitian tentang uji aktivitas senyawa flavonoid total dari Gynura Segetum (Lour) terhadap peningkatan eritrosit memberikan pengaruh nyata terhadap kenaikan eritrosit, hal tersebut diduga adanya kandungan senyawa flavonoid dari daun dewa ${ }^{12}$. Penelitian lain mengenai pemberian biji Garcinia kola yang mengandung bahan aktif flavonoid dapat meningkatkan kadar $\mathrm{Hb}$, jumlah eritrosit serta hematokrit. Akan tetapi, studi tentang minuman cokelat (Theobroma cacao L.) dan kaitannya dengan anemia masih sangat terbatas di Indonesia. Oleh karena itu, penelitian ini betujuan untuk mengetahui efek minuman cokelat terhadap jumlah eritrosit dan kadar $\mathrm{Hb}$ tikus putih (Rattus norvegicus) anemia ${ }^{13}$.

\section{BAHAN DAN METODE}

Penelitian ini menggunakan desain eksperimental dengan rancangan pretest-posttest control group design. Penelitian dilaksanakan pada bulan September sampai November 2018 di Laboratorium Biomedik Fakultas Kedokteran Gigi Universitas Jember. Teknik pengambilan sampel yang digunakan adalah simple random sampling. Penelitian menggunakan 21 ekor tikus jantan, usia 2-3 bulan, dan berat badan 200-300 gram. Tikus terbagi dalam 3 kelompok tikus yaitu kelompok kontrol negatif yaitu kelompok tikus normal yang diberi diet standart (pakan dan air), kelompok kontrol positif yaitu kelompok tikus anemia yang diberi diet standart (pakan dan air), dan kelompok perlakuan yaitu kelompok tikus anemia yang diberi diet standart serta di intervensi dengan minuman cokelat sebanyak 4,3 ml/ekor selama 14 hari. Induksi anemia pada kelompok tikus kontrol positif dan kelompok perlakuan menggunakan sonde Natrium Nitrit $\left(\mathrm{NaNO}_{2}\right)$ sebanyak $25 \mathrm{mg} / \mathrm{gBB}$ selama 18 hari, hal ini dilakukan agar tikus menjadi anemia . Parameter yang diamati pada penelitian ini adalah jumlah eritrosit dan kadar $\mathrm{Hb}$. Pengukuran jumlah eritrosit dan kadar $\mathrm{Hb}$ sebelum dan setelah intervensi dengan pengambilan darah melalui sinus orbitalis mata. Pengambilan sampel darah dilakukan pada hari ke-18 dan hari ke-32 tanpa puasa.

Data yang diperoleh di uji normalitas menggunakan shapiro-wilk., Uji one way ANOVA dan post hoc bonferroni digunakan untuk menganalisis perbedaan antar kelompok sebelum dan sesudah perlakuan dan untuk menganalisis efek minuman cokelat terhadap perubahan jumlah eritrosit dan kadar hemoglobin antar kelompok. Uji paired T-Test digunakan untuk menganalisis perbedaan sebelum dan sesudah perlakuan. Analisis data dilakukan dengan SPSS Statistics versi 22. Penelitian ini sudah mendapatkan 
persetujuan etik dari Komisi Etik Penelitian Kesehatan Politeknik Negeri Jember dengan No 8770/PL17/LL/2018 tanggal 24 Juli 2018.

\section{HASIL}

Jumlah eritrosit dan kadar $\mathrm{Hb}$ (pre test) setelah pemberian $\mathrm{NaNO}_{2}$ selama 18 hari menunjukkan penurunan pada kelompok kontrol positif dan perlakuan dibandingkan kontrol negatif. Hasil uji normalitas menggunakan shapiro wilk menunjukkan niai $\mathrm{p}>0,05$ yang artinya data jumlah eritrosit dan kadar $\mathrm{Hb}$ terdistribusi normal. Uji perbedaan jumlah eritrosit dan kadar $\mathrm{Hb}$ antar kelompok menggunakan uji parametrik one way ANOVA. Hasil uji beda jumlah eritrosit pretest antar kelompok perlakuan diperoleh nilai $\mathrm{p}=0,000$ (tabel 1), artinya terdapat perbedaan yang signifikan antar kelompok perlakuan. Hasil uji one way ANOVA dilanjutkan menggunakan uji post hoc bonferroni.

Tabel 1. Perbedaan Jumlah Eritrosit Antar Kelompok Sebelum Perlakuan (Pre Test)

\begin{tabular}{cccc}
\hline Perlakuan & Mean \pm Standar Deviasi (juta/Ul) & p value & Post hoc bonferroni \\
\hline Kontrol negatif & $8,9 \pm 0,6$ & & $\mathrm{a}$ \\
Kontrol positif & $7,01 \pm 0,67$ & $0,000^{*}$ & $\mathrm{~b}$ \\
Perlakuan (P) & $6,97 \pm 0,61$ & & $\mathrm{~b}$ \\
\hline
\end{tabular}

Keterangan :*uji One way ANOVA (p < 0,05) (Data Primer, 2018)

Tabel 2. Perbedaan Kadar Hb Antar Kelompok Sebelum Perlakuan (Pre Test)

\begin{tabular}{cccc}
\hline Perlakuan & Mean \pm Standar Deviasi $(\mathbf{g} / \mathbf{d l})$ & $\boldsymbol{p}$ value & post hoc bonferroni \\
\hline Kontrol Negatif & $16 \pm 1,06$ & & $\mathrm{a}$ \\
Kontrol Positif & $13,9 \pm 1,8$ & $0,011^{*}$ & $\mathrm{~b}$ \\
Perlakuan & $14,1 \pm 1,03$ & & $\mathrm{~b}$ \\
\hline
\end{tabular}

Keterangan : *uji One way ANOVA (p < 0,05) (Data Primer, 2018)

Tabel 3. Perbedaan Jumlah Eritrosit Antar Kelompok Setelah Perlakuan (Post Test)

\begin{tabular}{cccc}
\hline Perlakuan & Mean \pm Standar Deviasi (Juta/Ul) & p value & post hoc bonferroni \\
\hline Kontrol Negatif & $8,9 \pm 0,66$ & & $\mathrm{a}$ \\
Kontrol Positif & $7,3 \pm 0,59$ & $0,000^{*}$ & $\mathrm{~b}$ \\
Perlakuan & $9,3 \pm 0,78$ & & $\mathrm{a}$ \\
\hline
\end{tabular}

Keterangan : *uji One way ANOVA (p < 0,05) (Data Primer, 2018)

Tabel 4. Perbedaan Kadar Hb Antar Kelompok Setelah Perlakuan (Post Test)

\begin{tabular}{cccc}
\hline Perlakuan & Mean \pm Standar Deviasi (g/dl) & p value & post hoc bonferroni \\
\hline Kontrol Negatif & $16,3 \pm 0,37$ & & $\mathrm{a}$ \\
Kontrol Positif & $14,56 \pm 1,16$ & $0,001 *$ & $\mathrm{~b}$ \\
Perlakuan & $16,2 \pm 0,72$ & & $\mathrm{a}$ \\
\hline
\end{tabular}

Keterangan : *uji One way ANOVA (p < 0,05) (Data Primer, 2018)

Hasil uji post hoc bonferroni jumlah eritrosit pretest didapatkan pada kelompok yang diinduksi $\mathrm{NaNO}_{2}$ (kontrol positif dan perlakuan) menunjukkan perbedaan signifikan dibandingkan kontrol negatif. Hal ini menunjukkan bahwa penginduksian $\mathrm{NaNO}_{2}$ sebanyak 0,8 gram dapat menurunkan jumlah eritrosit secara signifikan pada kelompok perlakuan dan kontrol positif (tabel 1).

Hasil uji beda one way ANOVA kadar $\mathrm{Hb}$ pretest antar kelompok perlakuan diperoleh nilai $\mathrm{p}$ 0,011 (tabel 2), artinya terdapat perbedaan yang signifikan antar kelompok perlakuan. Hasil uji one way ANOVA dilanjutkan menggunakan uji post hoc bonferroni.
Hasil uji post hoc bonferroni kadar $\mathrm{Hb}$ pretest adalah terdapat perbedaan signifikan antara kelompok yang diinduksi $\mathrm{NaNO}_{2}$ dibandingkan kontrol negatif. Hal ini menunjukkan bahwa penginduksian $\mathrm{NaNO}_{2}$ 0,8 gram dapat menurunkan kadar $\mathrm{Hb}$ secara signifikan pada kelompok kontrol positif dan perlakuan (tabel 2).

Hasil analisis uji beda jumlah eritrosit antar kelompok sesudah pemberian minuman cokelat diperoleh nilai $\mathrm{p}=0,00$ artinya terdapat perbedaan signifikan jumlah eritrosit pada antar kelompok perlakuan. Hasil uji one way ANOVA dilanjutkan ke uji post hoc bonferroni. Dari hasil uji post hoc bonferroni dapat diketahui bahwa pemberian minuman cokelat memberikan pengaruh terhadap 
peningkatan jumlah eritrosit pada kelompok perlakuan apabila dibandingkan dengan kelompok kontrol positif. Hal tersebut ditunjukkan dengan jumlah eritrosit pada kelompok perlakuan lebih tinggi dibandingkan kelompok kontrol negatif dan kontrol positif (tabel 3).

Hasil analisis One Way Anova pada kadar $\mathrm{Hb}$ sesudah pemberian minuman cokelat diperoleh nilai $\mathrm{p}$ 0,001 artinya bahwa terdapat perbedaan kadar $\mathrm{Hb}$ antar kelompok perlakuan. Hasil uji one way ANOVA dilanjutkan ke uji post hoc bonferroni.

Berdasarkan hasil dari uji post hoc dapat diketahui bahwa pemberian minuman cokelat memberikan pengaruh terhadap peningkatan kadar $\mathrm{Hb}$ pada kelompok perlakuan apabila dibandingkan dengan kelompok kontrol positif. Hal tersebut ditunjukkan dengan kadar $\mathrm{Hb}$ pada kelompok perlakuan lebih tinggi dibandingkan kelompok kontrol positif (tabel 4).

Tabel 5. Perbedaan Jumlah Eritrosit Sebelum dan Sesudah Intervensi

\begin{tabular}{cccc}
\hline Kelompok & Pre Test $($ juta/Ul) & Post Test $(\mathbf{j u t a} / \mathrm{UI})$ & p value \\
\hline Kontrol Negatif & $8,9 \pm 0,68$ & $8,94 \pm 0,66$ & 0,941 \\
Kontrol Positif & $7,01 \pm 0,67$ & $7,3 \pm 0,59$ & $0,008^{*}$ \\
Perlakuan & $6,97 \pm 0,62$ & $9,23 \pm 0,77$ & $0,000^{*}$ \\
\hline
\end{tabular}

Keterangan : uji paired T Test $(*$ signifikan, $\mathrm{p}<0,05)$ (Data Primer, 2018)

Tabel 6. Perbedaan Kadar Hb Sebelum dan Sesudah Intervensi

\begin{tabular}{cccc}
\hline Kelompok & Pre Test $\mathbf{( g / d L )}$ & Post Test $\mathbf{( g / d L )}$ & $\boldsymbol{p}$ \\
\hline Kontrol Negatif & $16,2 \pm 1,01$ & $16,3 \pm 0,37$ & 0,688 \\
Kontrol Positif & $13,9 \pm 1,78$ & $14,6 \pm 1,16$ & 0,069 \\
Perlakuan & $14,12 \pm 1,03$ & $16,2 \pm 0,72$ & $0,002^{*}$ \\
\hline
\end{tabular}

Keterangan : uji paired T Test $(*$ signifikan, $\mathrm{p}<0,05)$ (Data Primer, 2018)

Berdasarkan hasil analisis statistik maka diketahui bahwa jumlah eritrosit pada kontrol positif dan perlakuan menunjukkan perbedaan signifikan antara sebelum dan sesudah intervensi. Seharusnya pada kelompok kontrol positif tidak mengalami peningkatan jumlah eritrosit, hal tersebut dimungkinakan karena pada saat intervensi induksi NaNO2 dihentikan sehingga menyebabkan tikus kembali kepada keadaan normal. Meskipun demikian, kenaikan jumlah eritrosit tidak sebanyak pada kelompok perlakuan. Kelompok perlakuan mengalami peningkatan jumlah eritrosit yang signifikan setelah diberikan minuman cokelat dengan dosis $4,3 \mathrm{ml} /$ hari selama 14 hari. Jumlah eritrosit pada kelompok perlakuan mengalami peningkatan sebanyak 2,258 juta/UI (tabel 5).

Berdasarkan hasil analisis statistik diketahui bahwa kadar $\mathrm{Hb}$ pada kelompok kontrol negatif dan kontrol positif tidak terdapat perbedaan signifikan antara sebelum dan sesudah intervensi. Kelompok perlakuan mengalami peningkatan kadar $\mathrm{Hb}$ yang signifikan setelah diberikan minuman cokelat dengan dosis 4,3 $\mathrm{ml} /$ hari selama 14 hari. Peningkatan kadar $\mathrm{Hb}$ pada kelompok perlakuan sebanyak 2,11 g/dL (tabel 6).

\section{PEMBAHASAN}

Jumlah eritrosit dan kadar $\mathrm{Hb}$ pada kelompok kontrol positif dan perlakuan mengalami penurunan secara signifikan dibandingkan dengan kontrol negatif (tabel 1 dan 2) setelah pemberian $\mathrm{NaNO}_{2}$ selama 18 hari. $\mathrm{NaNO}_{2}$ merupakan bahan pengawet yang dapat mempengaruhi kemampuan eritrosit untuk membawa oksigen, menyebabkan anemia dan membentuk nitrosamin yang bersifat karsinogenik ${ }^{14}$. Nitrit yang masuk kedalam tubuh dapat mempengaruhi kemampuan eritrosit dalam membawa oksigen. Kemampuan eritrosit yang berkurang untuk membawa oksigen terjadi karena $\mathrm{Hb}$ dalam eritrosit berikatan dengan NO membentuk nitrosohemoglobin. Ikatan antara nitrit dan $\mathrm{Hb}$ dapat menginduksi pembentukan Reactive Oxygen Spesies (ROS) dan menyebabkan stres oksidatif pada membran sel eritrosit sehingga eritrosit mengalami hemolisis ${ }^{1}$. Nitrit juga bisa menyebabkan anemia dengan adanya penelitian yang menunjukkan hasil penurunan angka eritrosit daan $\mathrm{Hb}$ pada penggunaan nitrit secara berlebihan. Peningkatan pembentukan ROS yang berujung pada stres oksidatif akan menyebabkan berbagai kerusakan hepar, yang merupakan target utama dari $\operatorname{ROS}^{15}$. Stres oksidatif yang terjadi pada sel darah merah mengakibatkan kadar eritropoietin 
turun dan mengganggu sintesis $\mathrm{Hb}^{16}$. Selain itu stres oksidatif juga mengakibatkan integritas sel darah merah menjadi lemah sehingga sel darah merah menjadi sangat sensitif dan mudah lisis ${ }^{17}$.

Pemberian minuman cokelat terbukti meningkatkan jumlah eritrosit dan kadar $\mathrm{Hb}$ secara signifikan pada kelompok perlakuan. Hal tersebut disebabkan karena minuman cokelat mengandung flavonoid yang merupakan antioksidan untuk melawan ROS. Flavonoid yang terkandung dalam bubuk cokelat dapat melawan ROS pada tikus diabetes melitus yang ditandai dengan penurunan kadar gula darah puasa ${ }^{14}$.

Penelitian tentang uji aktivitas senyawa flavonoid total dari Gynura Segetum (Lour) memberikan pengaruh nyata terhadap jumlah eritrosit ${ }^{3}$. Flavonoid merupakan senyawa polifenol yang berperan sebagai antioksidan, yang di dalam sel darah dapat bertindak sebagai penampung radikal hidroksil dan superoksida sehingga melindungi lipid membran dan mencegah kerusakan sel darah. Penelitian lain menyatakan bahwa ekstrak etanol meniran dapat meningkatkan jumlah eritrosit dan membuktikan ada peningkatan jumlah eritrosit pada tikus putih (Rattus norvegicus) strain wistar sebelum dan sesudah pemberian air seduhan kelopak bunga rosela merah $^{17}$. Air seduhan kelopak rosela merah dapat meningkatkan jumlah eritrosit karena mengandung pigmen antosianin (flavonoid) yang berperan sebagai antioksidan. Hasil penelitian tentang pemberian ekstrak daun sambung nyawa selama 10 hari mampu memperbaiki kadar $\mathrm{Hb}$ dalam darah tikus putih ${ }^{17}$.

Pada kelompok kontrol positif juga terjadi peningkatan jumlah eritrosit yang signifikan meskipun tidak diintervensi apapun. Hal ini tidak sesuai harapan, peningkatan jumlah eritrosit pada kelompok kontrol positif dikarenakan proses eritropoisis sudah terjadi. Pembentukan eritrosit diatur oleh suatu hormon glikoprotein yang disebut eritropoietin. Pembentukan eritrosit ini juga dapat dipengaruhi oleh fatktor lain yaitu protein ${ }^{15}$. Akan tetapi, kadar $\mathrm{Hb}$ pada kelompok kontrol positif tidak mengalami peningkatan yang signifikan. Hal tersebut dikarenakan proses pembentukan $\mathrm{Hb}$ yang lebih lama dibandingkan peningkatan jumlah eritrosit. Hal ini sejalan dengan penelitian sebelumnya dimana pemberian bubuk kakao sebanyak 2,6 gram dapat meningkatkan kadar $\mathrm{Hb}$ pada tikus anemia secara signifikan ${ }^{18}$. Pada proses hematopoesis yang pertama terbentuk adalah eritrosit yang diatur oleh hormon glikoprotein yang disebut eritropoietin. Sel pertama yang diketahui sebagai rangkaian pembentukan eritrosit disebut proeritorblas. Sel-sel baru dari generasi pertama ini disebut sebagai basofil eritroblas sebab dapat dicat dengan warna basa. Sel-sel ini mengandung sedikit sekali $\mathrm{Hb}$. Pada tahap berikutnya baru akan mulai terbentuk cukup $\mathrm{Hb}$ yang disebut polikromtofil eritroblas ${ }^{15}$.

\section{SIMPULAN}

Berdasarkan penelitian yang telah dilakukan maka dapat disimpulkan bahwa minuman cokelat berefek terhadap peningkatan jumlah eritrosit dan kadar $\mathrm{Hb}$ tikus anemia.

\section{DAFTAR PUSTAKA}

1. Purbadewi L, Ulvie YN. Hubungan Tingkat Pengetahuan Tentang Anemia Dengan Kejadian Anemia Pada Ibu Hamil. Jurnal Gizi. 2013;2(1).

2. Ambarwati R. Effect of Sodium Nitrite ( NaNO 2 ) to Erithrocyte and Hemoglobin Profile in White Rat (Rattus norvegicus). Folia Medica Indonesiana. 2012;48(1):1-5. http://journal.unair.ac.id/filerPDF/fmi0fbe2803b5f ull.pdf. [diakses: 13 Maret 2019).

3. World Health Organization (WHO). Global Prevalence of Anaemia. Geneva. 2015.

4. Sundaryono. Uji Aktivitas Senyawa Flavonoid Total dari Gynura segetum (Lour) Terhadap Peningkatan Eritrosit Dan Penurunan Leukosit Pada Mencit (Mus musculus).Jurnal Exacta, 2011;(9)2:8-16.

5. Kementerian Kesehatan Republik Indonesia. Riset Kesehatan Dasar. Jakarta. 2013.

6. Li S, Tan H, Wang N, Zhang Z, Lao L, Wong C, et al. The Role of Oxidative Stress and Antioxidants in Liver Diseases. 2015;10:26087-124.

7. Camaschella C. Iron-deficiency anemia. N Engl J Med. 2015; 7;372(19):1832-43.

8. Yue Y, Wang Y, Li D, Song Z, Jiao H, Lin H. A central role for the mammalian target of rapamycin in LPS-induced anorexia in mice. J. Endocrinol. 2015;1;224:37-47.

9. Mita N. Formulasi Krim dari Kulit Buah Kakao (Theobroma cacao L.) Berkhasiat Antioksidan. Journal of Tropical Pharmacy and Chemistry. 2015;30;3(1):12-21.

10. Restuti, A. N. S., Yulianti, A., Oktafa, H., Alfafa,DN., Yani, FN., Kurniati, M., Wulandari, P., Analisis Aktivitas Antioksidan dan Uji 
Organoleptik Minuman Cokelat (Theobroma cacao L. Prosiding Seminar Nasional INAHCO. 2019:1318. https://publikasi.polije.ac.id/index.php/inahco/artic le/view/1763/1105.

11. Restuti, A. N. S., Yulianti, A., Nuraini, N. Intervensi Bubuk Kakao terhadap Perubahan Kadar Gula Darah Puasa Tikus Sprague dawley Diabetes Melitus. Jurnal Riset Kesehatan. 2018;7(2):57-60. http://ejournal.poltekkessmg.ac.id/ojs/index.php/jrk/article/view/3646/946.

12. Mazhar M, Faizi S, Gul A, Kabir N, Simjee SU. Effects of naturally occurring flavonoids on ferroportin expression in the spleen in iron deficiency anemia in vivo. RSC Adv. 2017;7(38):23238-45.

13. Fibach E, Rachmilewitz E. The Role of Oxidative Stress in Hemolytic Anemia. Current Molecular Medicine. 2008;609-19.

DOI : 10.2174/156652408786241384 http://www.eurekaselect.com/67891/article (diakses 13 Maret 2019)

14. Unigwe, C.R. dan P.E. Nwakpu. 2009. Effect of Ingestion of Garcinia kola Seed on Erythrocytes in Rabbits. Continental Journal. Veterynary Sciences 2009;3:7-10
15. Lin CY, Hsiao WC, Huang CJ, Kao CF, Hsu GS. Heme oxygenase-1 induction by the ROS-JNK pathway plays a role in aluminum-induced anemia. J Inorg Biochem. 2013;1(128):221-8.

16. Yuningsih. Keracunan nitrat-nitrit pada ternak ruminansia dan upaya pencegahannya. Bogor : Balai Besar Penelitian Veteriner. 2007

17. Zulkifli., Maruni, W.D., Yunan, J., Laksmi, S. Jumlah Eritrosit Darah Tepi Hewan Coba Tikus Putih (Rattus norvegicus) Strain Wistar Yang Diberikan Air Seduhan Kelopak Bunga Rosela Merah (Hibiscus sabdariffa). Media Bina Ilmiah. 2014;8(4):11-17. https://studylibid.com/doc/142500/2-jumlaheritrosit-darah-tepi-hewan-coba-tikus

18. Farikhah,A., Indriani, F., Yulianti, A., Restuti, ANS. Intervensi Bubuk Kakao Terhadap Kadar Hemoglobin Tikus Putih Galur Wistar Anemia. Prosiding Seminar Nasional INAHCO. 2019:8091.

https://publikasi.polije.ac.id/index.php/inahco/artic le/view/1771/1113. 